\title{
A "Maker Education + SPOC" Teaching Model for College Political Economics Courses
}

\author{
https://doi.org/10.3991/ijet.v14i03.10103 \\ Yunling Fu \\ Qufu Normal University, Qufu, China \\ $3352165615 @ q q \cdot c o m$
}

\begin{abstract}
Analysis of the advantages of using the "maker education + SPOC" teaching model in college political economics courses from the perspective of maker education and SPOC reveals that this model can improve the teaching quality of political economics courses and cultivate students' innovation ability and problem solving skills. Based on the offline teaching system, the model of applying "maker education + SPOC" in college political economics courses was designed from the aspects of teaching environment, teaching process and teaching evaluation, and Shandong Normal College in Shandong Province was took as a case to carry out a study on the teaching practice and teaching effect of the model. It was found that the model can positively influence the teaching effect of college political economics courses, and opinions and suggestions were put forward on the practice of the model.
\end{abstract}

Keywords-SPOC, maker education, teaching reform, college political economics courses

\section{$1 \quad$ Introduction}

In recent years, China's information technology, especially Internet technology, has developed rapidly. In the era of Internet economy, innovation and training of innovative talents are the ultimate goal of higher education. Under the background of "Internet +" featured by maker education based on the concept of open innovation, the combination of online and offline teaching has become a hot topic in the education sector. The original meaning of Maker is manufacturer, and now Maker refers to a group of individuals who, driven by their own interests and hobbies, use various emerging scientific technologies to innovate bravely and turn their ideas into realities [1]. Its cores are creativity, innovation, and sharing, which are consistent with the commitment of higher education to foster innovative talents with innovation thinking, innovation awareness, and innovation ability. Higher education requires teaching in practice, and this concept also coincides with the spirit of Maker [2]. SPOC is the acronym for Small Private Online Course, which means small-scale restrictive or private online course. It combines traditional classroom teaching, absorbs the advantages of MOOC (Massive Open Online Course) and avoids the shortcomings of $\mathrm{MOOC}$, in order to make up for the shortage of traditional school course teaching. 
This teaching model is intended to realize the deep integration of education and information technology, and promote the development of educational information and teaching reform [3]. It is of practical and guiding significance to combine maker education with SPOC and explore how to integrate the model into college political economics courses, thereby to improve the learning ability and creativity of college students in political economics courses, to meet the classroom learning needs of college students, and to promote the reform of political economics teaching for college students.

\section{State of the Art}

In 2001, the MIT Center for Bit and Atomic Research launched a novel research experiment: Fab Lab (Fabrication Laboratory) [4], which is the origin of Maker. Its core concept is personal manufacturing. In addition to advocating personal design, it also advocates collective creation and cross-border cooperation. In 2012, Chris Anderson pointed out that the soul of Maker is innovation, practice and sharing [3]. In the same year, 1,000 American primary and secondary schools began to implement the educational model of maker space, and gradually formed maker education which aims to enhance students' creativity and enhance their ability to solve problems [5]. In 2015, the Chinese government determined the development policy to support maker space. In September of the same year, the Ministry of Education proposed "exploration of maker education and other new education models" [6]. Maker education has two connotations. One is maker education, aiming to cultivate maker talents; the other is maker education, meaning the use of the methods and concept of Maker to reform education and break through the limitations of traditional teaching [7]. The comparison between traditional education and maker education is shown in Table 1 below.

Table 1. Comparison between traditional education and maker education

\begin{tabular}{|l|l|l|}
\hline Comparison aspect & \multicolumn{1}{|c|}{ Traditional education } & \multicolumn{1}{c|}{ Maker education } \\
\hline Learning group & Same age, same major & Cross-age, cross-major \\
\hline Learning mode & Same discipline & interdisciplinary \\
\hline Learning content & Theory & $\begin{array}{l}\text { Theory + practice, with more emphasis } \\
\text { on practice }\end{array}$ \\
\hline Learning goal & $\begin{array}{l}\text { Know, understand, and convey } \\
\text { knowledge }\end{array}$ & $\begin{array}{l}\text { Practice, create, share and solve prob- } \\
\text { lems }\end{array}$ \\
\hline Teaching method & Inculcation, single & $\begin{array}{l}\text { Integration with information technology, } \\
\text { diverse }\end{array}$ \\
\hline Learning method & Individual & Teamwork \\
\hline Learning place & classroom & Unlimited \\
\hline Teacher role & Center & Guider \\
\hline Student role & Passive recipients & Active, center, creator \\
\hline
\end{tabular}

After its launch in the United States in 2012, MOOC swept the world rapidly. Its large-scale, integration and openness were welcomed by universities and educational institutions, and MOOC platforms were established to achieve educational resource sharing and educational equity and cut down the cost of education, providing us with an online learning model. However, with continuous practice, it was found that 
MOOC has some obvious drawbacks, such as high investment, high dropout rate, low completion rate, less acquaintance between teachers and students, and unmanageable learning behaviors, which have caused the low efficiency of MOOC. SPOC was subsequently proposed to make full use of the advantages of traditional teaching and realize the value of MOOC at the same time [8]. SPOC integrates traditional classroom teaching with MOOC resources to form a high-performance online and offline teaching combination model. In 2013, Armando Fox, director of the MOOCLab [9] program at the College of California, Berkeley, first put forward SPOC, hoping to integrate MOOC with traditional classroom and adopting concepts including minority education, micro-class, and integrated education. Hence, offline classroom teaching becomes flexible, fun and efficient. SPOC has two models. One is the use of MOOC version or MOOC plus Classroom by local students. The other is the selection of a small number of online students according to specific conditions [10]. SPOC combines the advantages of MOOC and classroom teaching. The comparison of the characteristics of SPOC and MOOC teaching model is shown in Table 2 below.

Table 2. Comparison between SPOC and MOOC

\begin{tabular}{|l|l|l|}
\hline Comparison aspect & \multicolumn{1}{|c|}{ SPOC } & \multicolumn{1}{c|}{ MOOC } \\
\hline Objects & Restricted selection & All \\
\hline Student size & Small, a limited number & Large, unlimited \\
\hline Learning mode & $\begin{array}{l}\text { Independent learning, teamwork + teacher } \\
\text { instruction }\end{array}$ & Independent learning \\
\hline Learning process & Long, 1 semester & Short, 4-8 weeks \\
\hline Learning interaction & Online + offline, more interactions & Online, fewer interactions \\
\hline Learning evaluation & Online + offline & Online \\
\hline Learning resources & $\begin{array}{l}\text { Online resources + real-time teaching } \\
\text { resources }\end{array}$ & Online resources \\
\hline Completion rate & High, nearly $100 \%$ & Low, roughly $10 \%$ \\
\hline Implementation cost & Low & High \\
\hline Teaching effect & High & Low \\
\hline
\end{tabular}

\section{Specific Design of college Political Economics courses based on the "Maker Education + SPOC" Model}

\subsection{Technological foundation of the teaching design}

Under the "maker education + SPOC" model, the teaching design of college political economics courses adopts the patented offline teaching system for technical support, combines teaching content of political economics courses, produces courseware via the offline client, and then achieves synchronization of the courseware between the offline client and cloud server. Teachers can download and demonstrate the courseware at the lecture location, and edit the courseware at the same time, such as labeling, scribing, recording, etc. It is convenient for teachers to teach and students to learn. The structure of the offline teaching system for political economics courses is shown in Figure 1. 


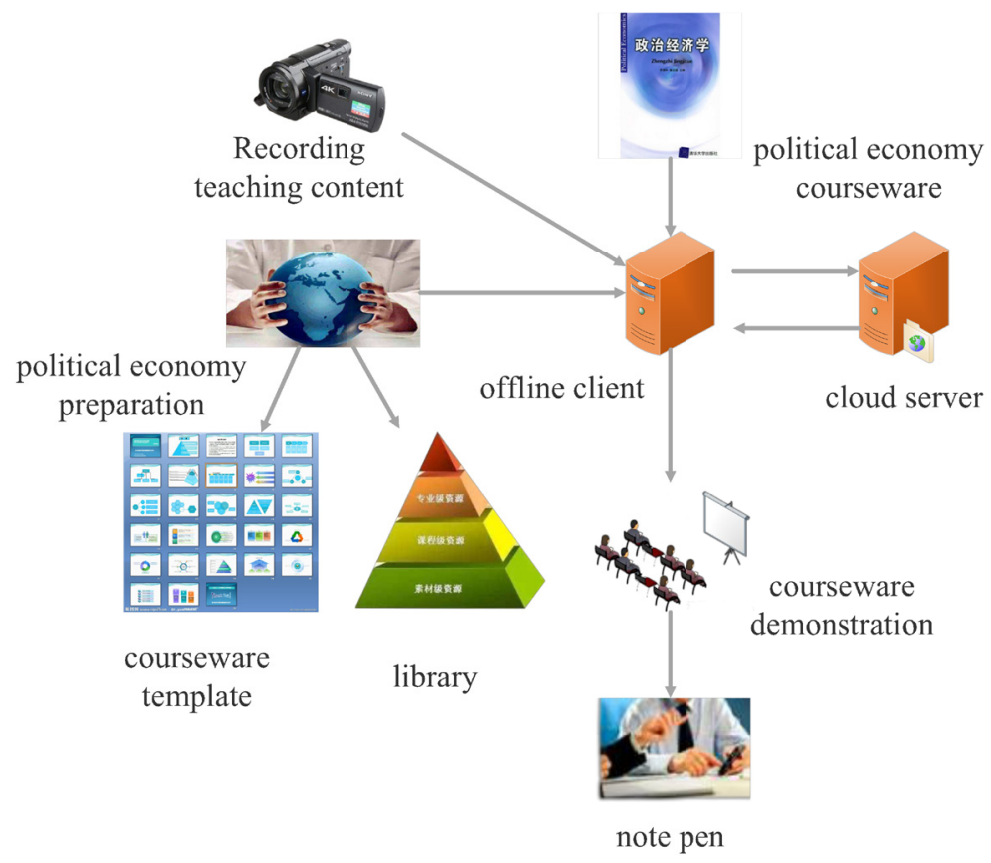

Fig. 1. Offline teaching system for political economics courses

\subsection{Design of the teaching environment}

The teaching environment of college political economics courses under the "maker education + SPOC" model includes the online learning environment and the offline learning environment. Particularly, the online learning environment is the SPOC Internet learning environment, including registration, resources and SPOC platforms; the offline learning environment is the environment suitable for SPOC teaching, such as classrooms, lecture halls, libraries, and dormitories, which can be accessed by college students on campus. The same teaching tools, including textbooks and related multimedia teaching hardware and software, are required for both the online and offline learning environment. The teaching environment is shown in Table 3 below.

Table 3. Teaching environment of college political economics courses under the "maker education + SPOC" model

\begin{tabular}{|l|l|}
\hline \multicolumn{1}{|c|}{ Online learning environment } & \multicolumn{1}{c|}{ Offline learning environment } \\
\hline Registration: Register by name, student number & Classroom, lecture hall, library, dormitory, etc. \\
\hline $\begin{array}{l}\text { Resources: Related materials of political econom- } \\
\text { ics, test database, media database }\end{array}$ & Teachers: Online Q\&A, Interaction \\
\hline $\begin{array}{l}\text { Platform: Online learning, communication, and } \\
\text { results presentation }\end{array}$ & Students: grouping, 5-10 members \\
\hline Teaching tools: textbooks, computers, projectors, cameras, mobile phones, networks, etc. \\
\hline
\end{tabular}




\subsection{Design of the learning form}

Combéfis et al. converted traditional courses into two paths: SPOC path and traditional course path. On this basis, the "learning form" dimension was added to generate the three-dimensional structure of the SPOC-based time-space-learning form (as shown in Figure 2).

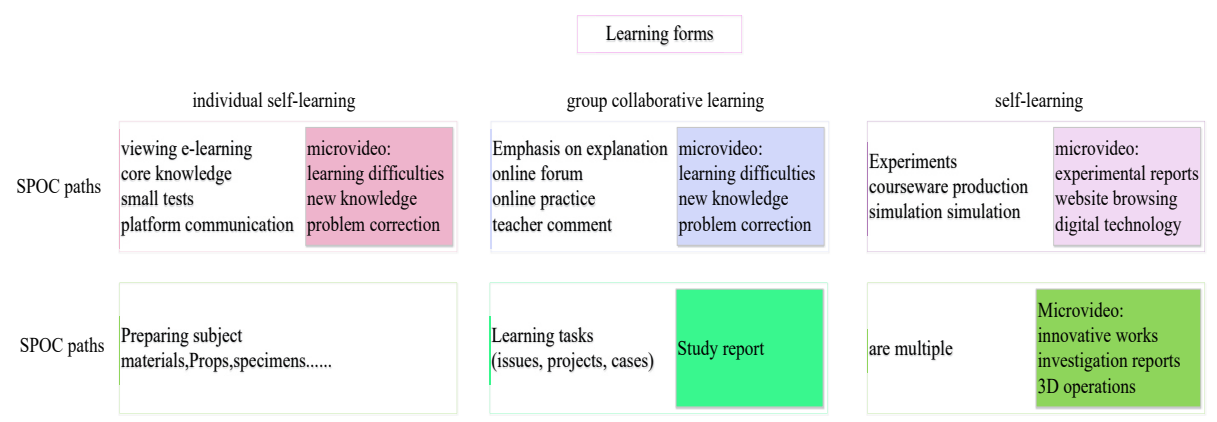

Fig. 2. Relationship structure of the SPOC-based time-space-learning form

It can be seen from Figure 2 that learning forms mainly include self-learning, cooperative learning and inquiry learning. From the perspective of time, the teaching process is roughly divided into three stages: the initial learning stage, the in-depth learning stage, and the stage of application and innovation. These three stages spiral up, usually with certain periodicity, and basically correspond to the three learning forms above. From the spatial perspective, hybrid learning always combines "online" (SPOC path) with "offline" (traditional course path), commonly known as the $\mathrm{O} 2 \mathrm{O}$ (Online to Offline) model [11]. For example, in the stage of application and innovation, on the one hand, it is necessary to give play to the leading role of the knowledge network in cognition, to better integrate the knowledge and skills learned, and to apply it to more complex real life scenarios. On the other hand, it is critical to modify and improve one's own core knowledge network according to different environments and needs. The observation points here include various offline products (such as prototypes, survey reports, etc.), and may also include digital simulations on SPOC platforms, digital experiment reports, and WebQuest websites [12].

\subsection{Design of the teaching process}

Generally speaking, the teaching weeks of an ordinary college in China are 18 weeks per semester, and the teaching hours of a specialized course are generally 36 hours. However, the teaching materials used in different courses of political economics contain more or less teaching content. Hence, when adopting the "maker education + SPOC" teaching model for the teaching of political economics courses, the teaching hours should be determined and divided according to the content of the teaching materials. In the teaching design of political economics courses using the "maker education + SPOC" teaching model, the teaching of each unit is divided into four parts: 
development of preset learning resources of political economics courses, online use of preset resources of political economics courses, offline exploration of resources of political economics courses and formation of new resources, and generation of new open questions related to political economics courses. First of all, students' learning needs should be combined to constantly adjust the learning objectives; attention is paid to the practicality of the provided learning resources; classroom scenarios are designed according to students' real life, so as to stimulate their enthusiasm in practice; multi-dimensional methods, including various books, audios, pictures, videos, tests, etc. are used to inspire students' learning interests. Interactive approaches are provided to increase online and offline interactions; resources such as problems, exercises, discussions, etc., are employed to develop preset learning resources of political economics courses; it is also important to prepare for the class. Second, in the campus teaching environment, in the teaching of political economics related courses, students are allowed to learn and use online preset resources by themselves before class, and the teacher uses the prepared online preset learning resources to help students master the course content and obtain learning resources, and stimulates students to think, create and practice. Third, students combine their doubts about the process of selflearning and discussing online learning resources with learning tasks when engaged in online inquiry and communication with teachers and classmates, to produce new problems and generative resources, thereby providing new content for further learning. Fourth, students should evaluate and give feedback to their online and offline learning. Online assessment, guidance, and suggestions from offline teachers and classmates are combined with their own creation to solve their own problems. They need to combine theories with practice, and provide new development resources for political economics courses. These four parts form a cyclical, endless teaching process. The entire "maker education + SPOC" teaching model for college political economics courses is shown in Figure 3.

\subsection{Design of the teaching evaluation indicators}

Evaluation of the teaching of college political economics courses under the "maker education + SPOC" model is divided into two parts. One is the evaluation of teachers' teaching effect, and the other is the evaluation of students' learning effect. Considering that "maker education + SPOC" combines online education with offline education, its evaluation method can also combine online evaluation and offline evaluation. The offline evaluation indicators of teachers' teaching effect include student evaluation and peer review, while the online evaluation indicators can include the number of registered students, the design of online learning resources (student evaluation), the number of activities and the number of Q\&A. The offline evaluation indicator of students' learning effect is the final scores in political economics courses, while the online evaluation indicators can be the learning time, the active level (the number of interactions), and online evaluation results. In the actual inspection process, the indicators can be selected according to the specific circumstances. The teaching evaluation indicator system of college political economics courses under the "maker education + SPOC" model is shown in Table 4 . 


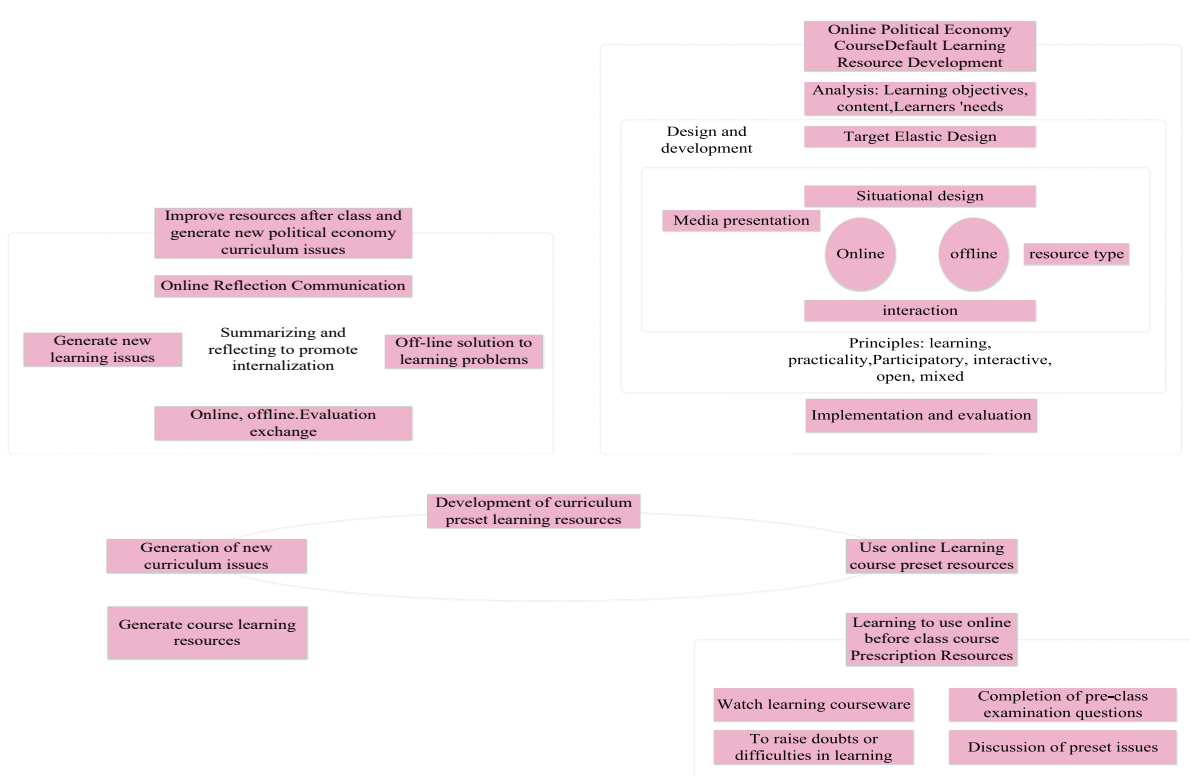

Fig. 3. The "maker education + SPOC" teaching model for college political economics courses

Table 4. Teaching evaluation indicator system of college political economics courses under the "maker education + SPOC" model

\begin{tabular}{|c|l|l|}
\hline Teaching evaluation & \multicolumn{1}{|c|}{ Online evaluation } & \multicolumn{1}{c|}{ Offline evaluation } \\
\hline Teachers' teaching effect & $\begin{array}{l}\text { Number of registered students } \\
\text { Learning resource design evaluation } \\
\text { Number of activities } \\
\text { Learning management } \\
\text { Number of interactions }\end{array}$ & $\begin{array}{l}\text { Student evaluation } \\
\text { Peer review }\end{array}$ \\
\hline Students' learning effect & $\begin{array}{l}\text { Learning time } \\
\text { Number of interactions } \\
\text { Number of activities participated } \\
\text { Online test results }\end{array}$ & Final score \\
\hline
\end{tabular}

\section{Influence of the "Maker Education + SPOC" Teaching Model on college students' learning Interest and Academic Achievement}

In this study, two classes, respectively $\mathrm{A}$ and $\mathrm{B}$, of the same grade of political economics in Shandong Normal College were selected as the research objects. Class A and Class B is both composed of 32 students with similar academic achievements in their specialized courses and taught by the same teachers. Class A is the experiment group, and the "maker education + SPOC" teaching model was adopted for the teaching of political economics related courses. Class B is the control group, and the previ- 
ous teaching model was still used for teaching. A one-semester teaching practice was conducted from September 2017 to January 2018. Before and after the experiment, the attitudes of Class A and Class B on political economics courses were examined, and their scores in relevant courses were compared, to analyze the role of the "maker education + SPOC" teaching model in political economics courses.

The teaching effect of this experiment was evaluated mainly through the offline evaluation of students' learning effect. The final results in political economics courses were counted, and the results were analyzed by mean, standard deviation and significance test- $Z$ test. At the same time, the frequency of changes in students' interest in political economics was examined to identify students' attitude changes.

\subsection{Influence on learning interest}

Questionnaire surveys were conducted in Class A and Class B before and after the experiment to examine their learning interest in political economics courses. The statistical results are shown in Table 5 below. It can be seen that before the experiment, 10 members in the experiment group are very interested in political economics courses, accounting for $31.3 \% ; 8$ members are relatively interested, accounting for $25.0 \% ; 8$ members have no special interest, accounting for 25.0\%; 6 members are not interested, accounting for $18.8 \%$. 11 members in the control group are very interested in political economics courses, accounting for $34.4 \%$; 10 members are relatively interested, accounting for $31.3 \%$; 8 members have no special interest, accounting for $25.0 \% ; 3$ members are not interested, accounting for $9.4 \%$. After the experiment, 17 members in the experiment group are very interested in political economics courses, accounting for $53.1 \%$; 13 members are relatively interested, accounting for $40.6 \%$; 2 members have no special interest, accounting for $6.3 \%$. 8 members in the control group are very interested in political economics courses, accounting for $25.0 \%$; 6 members are relatively interested, accounting for $18.8 \% ; 13$ members have no special interest, accounting for $40.6 \%$; 5 members are not interested, accounting for $15.6 \%$. It can be seen that after adopting the "maker education + SPOC" teaching model to teach college political economics courses, students' level of learning interest is significantly improved.

Table 5. Comparison of learning interest of the experiment and control group in political economics courses before and after the experiment

\begin{tabular}{|l|l|c|c|c|c|}
\hline \multicolumn{1}{|c|}{ Phrase } & \multicolumn{1}{c|}{ Class } & $\begin{array}{c}\text { Very } \\
\text { interested }\end{array}$ & $\begin{array}{c}\text { Relatively } \\
\text { interested }\end{array}$ & $\begin{array}{c}\text { No special } \\
\text { interest }\end{array}$ & $\begin{array}{c}\text { Not } \\
\text { interested }\end{array}$ \\
\hline Before & Experiment group & $10(31.3 \%)$ & $8(25.0 \%)$ & $8(25.0 \%)$ & $6(18.8 \%)$ \\
\cline { 2 - 6 } Experiment & Control group & $11(34.4 \%)$ & $10(31.3 \%)$ & $8(25.0 \%)$ & $3(9.4 \%)$ \\
\hline \multirow{2}{*}{$\begin{array}{l}\text { After } \\
\text { Experiment }\end{array}$} & Experiment group & $17(53.1 \%)$ & $13(40.6 \%)$ & $2(6.3 \%)$ & $0(0.0 \%)$ \\
\cline { 2 - 6 } & Control group & $8(25.0 \%)$ & $6(18.8 \%)$ & $13(40.6 \%)$ & $5(15.6 \%)$ \\
\hline
\end{tabular}

\subsection{Influence on academic achievement}

After the end of the semester using different teaching models, the final scores in four political economics related courses, including Introduction to the Basic Princi- 
ples of Marxism, Introduction to Mao Zedong Thought and the Theoretical System of Socialism with Chinese Characteristics, Ideological and Moral Cultivation and Legal Basis, Situation and Policy \& Contemporary World Economy and Politics. The results are shown in Table 6 below. It can be seen from Table 6 that after the "maker education + SPOC" teaching model was used in the experiment group, the average score of the experiment in each political economics course is higher than that of the control group, and the difference is roughly 7 points. The standard deviation is smaller than that of the control group, indicating that the fluctuation is also lower than that of the control group, and the test results are all significant at the level of 0.05 . Although it is impossible to completely control other conditions in the experiment and the improvement of the experiment group's scores may not be completely attributed to the "maker education + SPOC" teaching mode, it still shows that the model has positive effects on students' learning effect in political economics courses.

Table 6. Comparison of scores of the experiment and control group in political economics courses after the experiment

\begin{tabular}{|c|c|c|c|c|c|}
\hline Course & Class & $\mathbf{n}$ & Mean & $\mathbf{Z}$ & $P$ \\
\hline \multirow[t]{2}{*}{ Marxism } & Experimental group & 32 & $88.33 \pm 3.12$ & \multirow[t]{2}{*}{2.50} & \multirow[t]{2}{*}{$\mathrm{P}<0.05$} \\
\hline & Control group & 32 & $80.26 \pm 5.51$ & & \\
\hline \multirow{2}{*}{$\begin{array}{l}\text { MaoZedong } \\
\text { Thought }\end{array}$} & Experimental group & 32 & $88.87 \pm 4.35$ & \multirow[t]{2}{*}{2.20} & \multirow[t]{2}{*}{$\mathrm{P}<0.05$} \\
\hline & Control group & 32 & $82.35 \pm 6.79$ & & \\
\hline \multirow{2}{*}{$\begin{array}{l}\text { Ideological and } \\
\text { Moral Cultivation } \\
\text { and Legal Basis }\end{array}$} & Experimental group & 32 & $87.42 \pm 5.11$ & \multirow[t]{2}{*}{2.20} & \multirow[t]{2}{*}{$\mathrm{P}<0.05$} \\
\hline & Control group & 32 & $79.78 \pm 8.54$ & & \\
\hline \multirow[t]{2}{*}{ Situation Policy } & Experimental group & 32 & $89.02 \pm 6.91$ & \multirow[t]{2}{*}{2.60} & \multirow[t]{2}{*}{$\mathrm{P}<0.05$} \\
\hline & Control group & 32 & $81.65 \pm 9.33$ & & \\
\hline
\end{tabular}

From the investigation of the attitudes of Class A and Class B in political economics courses before and after the experiment, as well as their scores in the final exams, and the in-Class And after-class observation in the experiment, it can be clearly seen that the "maker education + SPOC" teaching model has a significant effect on the teaching of college political economics courses. It can be observed that under the "maker education + SPOC" teaching model, teachers and students have obvious positive changes in their attitudes towards political economics. The attendance rate of Class A is significantly higher than that of Class B, and their enthusiasm, participation and attention in Class Are also significantly higher than those of Class B. Class A's completion of tasks after Class A is obviously better than that of Class B. The same teacher is also more willing to take classes in Class A, has more energy and enthusiasm when teaching Class A, and is more willing to check student assignments of Class A and interact with the students of Class A. The results of the questionnaire also shows that Class A's learning interest in political economics courses is significantly improved after the experiment, while there is a slight decline among the students in Class B, since the number of students interested in political economics courses decreases. There is also a significant improvement in the scores of Class A in relevant political economics courses, and the gap with Class B clearly becomes larger. The "Maker education + SPOC" teaching model uses visualized teaching, and provides a large amount of learning resources. The teaching process is open, inquiring and col- 
laborative. The cooperation, communication and exchange between teachers and students are obviously enhanced. The thinking methods acquired from a course can also be applied to other courses to maximize the efficiency and effect of the teaching of political economics courses. In fact, the "maker education + SPOC" teaching model not only improves students' academic performance, but also enhances the teaching level of teachers. With the development of information technology, it is an inevitable trend to combine with the needs of higher education curriculum reform and innovation, cultivate innovative talents, make full use of the Internet, and integrate online and offline education to improve teaching quality and efficiency. Under the "maker education + SPOC" teaching model, the construction of college political economics courses can achieve better teaching effect.

\section{Conclusion}

In summary, it is believed that the application advantages of this model include:

\subsection{Improving the quality of teaching}

Integrating maker education and SPOC into college political economics courses can free teachers from blackboard writing and save classroom time. Studies have shown that the use of multimedia teaching can finish the content, which originally required 40 hours within 36 hours, so that there is more time to play teaching films, carry out classroom discussions, allow students to communicate independently or collect papers, etc., and thereby turn students into the subjects of the classroom. On the other hand, the e-learning courseware designed in advance is characterized by standardized writing and clear organization of the content, making it easier for students to master the knowledge points. Meanwhile, political economics courses are relatively boring, and students themselves are resistant to it but learn entirely for passing the exams. However, the maker education + SPOC teaching model takes rich visual and auditory effects to show the teaching content. Compared with the traditional inculcation teaching, this model makes it easier to concentrate students' attention, adjust the classroom atmosphere, arouse students' interest, improve teaching quality and teaching efficiency, and achieve better teaching effect.

\subsection{Fostering innovation ability and problem solving ability}

Applying the maker education and SPOC teaching model to the classroom of political economics can greatly enhance the intuitiveness, entertainment and vividness of political and economic content, thus enhancing students' attention, understanding and analytical ability and inspiring their creative thinking. In the maker education + SPOC teaching model, students are creators, practitioners and initiators. They should not only learn independently, collaborate and explore, but also practice, strive to create and share. The maker education and SPOC model provides students with an open teaching environment, rich teaching materials, and teacher guidance anytime and 
anywhere, produces systematic learning content according to the rules of knowledge and logic development, constantly corrects the practice objectives, adjusts and controls the direction of learning according to the practice process, and helps students generate and construct knowledge to form creative ideas and put them into practice. The maker education + SPOC teaching model integrates knowledge acquisition, learning experience and instructional design to provide a powerful guarantee for fostering students' ability to innovate and solve problems.

At the same time, it is believed that when practicing this model, we need to pay attention to the following aspects: Firstly, we must pay attention to the practicality and comprehensiveness of the development of preset resources, because the incompatible or incomplete materials and the failure to offer supplementary information in a timely manner would make it impossible to connect all the links. This affects students' enthusiasm for learning and lead to their failure to complete course tasks or solve specialized problems. Secondly, it is necessary to pay attention to the training of teachers' information technology; otherwise, teachers may resist the teaching model because they are not able to use related equipment and software. Instead, it is important to help teachers keep up with the times and fall in love with this teaching model. Thirdly, it is critical to rationally arrange the course content, pay attention to teaching management, and avoid students' use of mobile phones for activities that are not related to course learning because they are allowed to use mobile phones. Development of the strengths and avoidance of the weaknesses should be combined with the characteristics of political economics courses to construct a scientific and reasonable "maker education + SPOC" teaching model.

\section{Acknowledgement}

This work was supported by The youth fund project of the humanities and social sciences of the Ministry of Education (14YJC790030).

\section{$7 \quad$ References}

[1] Hosseini, A.S. University student's evaluation of creative education in universities and their impact on their learning. Procedia - Social and Behavioral Sciences, 2011, vol. 15, pp. 1806-1812. https://doi.org/10.1016/j.sbspro.2011.04.007

[2] Rojanapanich, P., Pimpa, N. Creative Education, Globalization and Social Imaginary. Creative Education, 2011, vol. 2(4), pp. 327-332. https://doi.org/10.4236/ce.2011.24046

[3] Lockhart, B.J., Capurso, N.A., Chase, I., et al. The Use of a Small Private Online Course to Allow Educators to Share Teaching Resources Across Diverse Sites: The Future of Psychiatric Case Conferences? Academic Psychiatry, 2017, vol. 41(1), pp. 81-85.

[4] Teng, C.K., Chuang, M.C., Hsu, C.C. Planning a Design Course for Play Experience and FabLab. Universal Journal of Educational Research, 2015, vol. 3(10), pp. 751-756. https://doi.org/10.13189/ujer.2015.031014

[5] P-Mar, V.N. Making God known, loved, and served: the future of Catholic primary and secondary schools in the United States. Catholic Education, 2008, vol. 11(2), pp. 276-312. 
[6] Zhu, L., Hu, X.Y. Research on Maker Education Oriented Design Based Learning: Model and Case. China Educational Technology, 2016, vol. 11, pp. 23-29.

[7] Ferch, S.R., John, I.S., Reyes, R., et al. Person-to-Person Learning: A Form of Creativity in Education. Journal of Humanistic Counseling, 2011, vol. 45(2), pp. 148-164. https://doi.org/10.1002/j.2161-1939.2006.tb00014.x

[8] Breslow, L., Pritchard, D.E., Deboer, J., et al. Studying Learning in the Worldwide Classroom Research into edX's First MOOC. Research \& Practice in Assessment, 2013, vol. 8, pp. 13-25.

[9] Godwinjones, R. Global Reach and Local Practice: The Promise of MOOCs. Language Learning \& Technology, 2014, vol. 18(3), pp. 5-15.

[10] Kang, Y.Q. An Analysis on SPOC: Post-MOOC Era of Online Education. Tsinghua Journal of Education, 2014, vol. 46(5), pp. 83-85.

[11] Zhao, F., Wu, D., Liang, L., et al. Lateral inventory transshipment problem in online-tooffline supply chain. International Journal of Production Research, 2016, vol. 54(7), pp. 1951-1963. https://doi.org/10.1080/00207543.2015.1070971

[12] Chang, C.S., Chen, T.S., Hsu, W.H. The study on integrating WebQuest with mobile learning for environmental education. Computers \& Education, 2011, vol. 57(1), pp. 12281239. https://doi.org/10.1016/j.compedu.2010.12.005

\section{Author}

Yunling Fu is a lecturer in the Qufu Normal University, Qufu, China (3352165615@qq.com).

Article submitted 29 September 2018. Resubmitted 25 November 2018. Final acceptance 29 November 2018. Final version published as submitted by the author. 